\title{
Effects of Nitrogen Exponential Fertilization on Growth and Nutrient Concentration of Hydrangea macrophylla Seedlings
}

\section{Xueying Wang ${ }^{1}$, Yonghong $\mathrm{Hu}^{2,3}$, Fiza Liaquat ${ }^{4}$, Xianquan Zhang ${ }^{2,3}$, Kang $\mathrm{Ye}^{2,3}$, Jun Qin ${ }^{2,3, *}$ and Qunlu Liu ${ }^{1, *}$}

\author{
${ }^{1}$ Department of Landscape Architecture, School of Design, Shanghai Jiao Tong University, Shanghai, 200240, China \\ ${ }^{2}$ Shanghai Engineering Research Center of Urban Tree Ecology and Applications, Shanghai, 200020, China \\ ${ }^{3}$ Shanghai Chen Shan Botanical Garden, Shanghai, 201602, China \\ ${ }^{4}$ School of Agriculture and Biology, Shanghai Jiao Tong University, Shanghai, 200240, China \\ *Corresponding Authors: Qunlu Liu. Email: liuql@sjtu.edu.cn; Jun Qin. Email: qinjun03@126.com
}

Received: 21 June 2021 Accepted: 03 August 2021

\begin{abstract}
Slow growth rate restricts the development and growth of seedlings due to nutrients deficiency or nutrient imbalance. Exponential fertilization can enhance the internal nutrient reserves in seedlings at the nursery-stage and strengthen their resistance to adverse conditions. In this study, nitrogen requirements for producing Hydrangea macrophylla 'Hanatemari' that robust seedlings, nutrient dynamics, biomass and growth, was examined utilizing exponential fertilization. The potted seedlings were fertilized with urea under exponential regime at rates of 0.5 , 1.5 and $2.0 \mathrm{~g}$ nitrogen/plant (EF1, EF2, and EF3), respectively. In addition, an unfertilized group treated with equal volume of deionized water was used as control. The results showed that seedlings under $1.5 \mathrm{~g} \mathrm{~N} / \mathrm{plant}$ (EF2) had the highest plant growth index and total biomass. The nutrient concentrations of different organs varied in different fertilization treatments. Based on the results of current study, it is concluded that $1.5 \mathrm{~g} \mathrm{~N} / \mathrm{plant}$ (EF2) is suitable exponential fertilization treatment for the culture of hydrangea seedlings. Our treatments results showed that $2.0 \mathrm{~g} \mathrm{~N} /$ plant is not suitable for seedling culturing, because of serious nutrient toxicity. These findings will help to improve seedling quality and strengthen the production of $H$. macrophylla for plantation.
\end{abstract}

\section{KEYWORDS}

Hydrangea macrophylla; nitrogen; exponential fertilization; containerized seedlings; nutrient loading; nutrient toxicity

\section{Introduction}

Hydrangea macrophylla is a deciduous shrub which is native to South China and Japan [1]. Because of the diversity of color and inflorescence shape, it has been widely used in the production of cut flowers and landscaping [2]. 'Hanatemari' is an excellent variety of big leaf Hydrangea, with beautiful inflorescence shape, bright flower color and strong resistance. It is commonly used in landscaping in Shanghai. Seedling quality is one of the important indicators which influence the later ornamental quality of the flower shrub [3]. Fertilization is an essential way to promote seedling growth and improve seedling quality. Nitrogen is an essential mineral element which affects plant growth [4]. However, there is still no report on the Hydrangea exponential fertilization experiment.

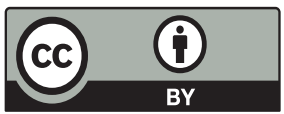

This work is licensed under a Creative Commons Attribution 4.0 International License, which permits unrestricted use, distribution, and reproduction in any medium, provided the original work is properly cited. 
The exponential fertilization technique is one of the three important ways to attain nutrient loading stage in seedlings and improve plant quality [5]. In the exponential fertilization scheme, the nutrients are applied in an exponential increasing way in order to adapt to the nutrient demand of plants in each growth stage [1]. The nutrient loading strategy, which is based on exponential fertilization, aims to boost seedling nutrient reserves by encouraging luxury nutrient consumption during nursery production [2]. Compared with the conventional fertilization method, exponential fertilization is an effective way to improve seedling quality and enhanced the $\mathrm{N}$ and $\mathrm{P}$ concentrations of different tree species such as black spruce (Picea mariana (Mill.) B.S.P.), white spruce (Picea glauca (Moench) Voss), pedunculate oak (Quercus robur L.), Chinese fir (Cunninghamia lanceolata (Lambert) Hooker), and others [6], and has become the first choice in containerized seedling cultivation, especially large trees with different growth rhythms, in many countries [7].

Nitrogen is one of the most important mineral elements which affect plant growth. It also plays a vital role in chlorophyll biosynthesis, so this element can promote the growth of the above-ground parts of the plant and gives the leaves a deeper green color [8]. In the case of nitrogen deficiency, plant growth will be suppressed, and the seedlings quality is poor due to the weakening of photosynthesis and enzyme catalysis. Because of the mobility of nitrogen in plants, the nitrogen deficiency characteristics is initially manifested in the old leaves, which is characterized by color changes from light green to light yellow [9]. Over-fertilization is uneconomical and may result in plant injury, pest and disease problems, and environmentally damaging nutrient leaching [10]. Seedling wilt is a specific manifestation of nutrient toxicity, and the biomass will no longer increase or even decrease as the amount of nutrients increases. Studies have shown that the method of exponential fertilization can effectively improve the utilization efficiency of plant nutrients, so the study of exponential fertilization of nitrogen is of great significance to improve the nitrogen absorption and utilization efficiency and improve the quality of seedlings [11].

We hypothesized that the exponential fertilization could improve the growth and the nutrients reserves in organs of Hydrangea seedlings. To evaluate this, a pot experiment was carried out under different dosages, which could provide a rational $\mathrm{N}$ fertilizer application strategy for the nutrient management.

\section{Material and Method}

\subsection{Study Area}

The experiment was carried out at the nursery of Chen Shan botanical garden located in Songjiang District, Shanghai (31.08N, 121.77E) (Fig. 1). It has a north subtropical maritime monsoon climate with an annual average air temperature of $18.5^{\circ} \mathrm{C}$, ranging from $0^{\circ} \mathrm{C}$ to $37^{\circ} \mathrm{C}$ in 2019 . The annual average precipitation is $1123 \mathrm{~mm}$. The temperature in the nursery ranged from $8^{\circ} \mathrm{C}$ to $36^{\circ} \mathrm{C}$ during the experimental period (from April 2019 to September 2019).
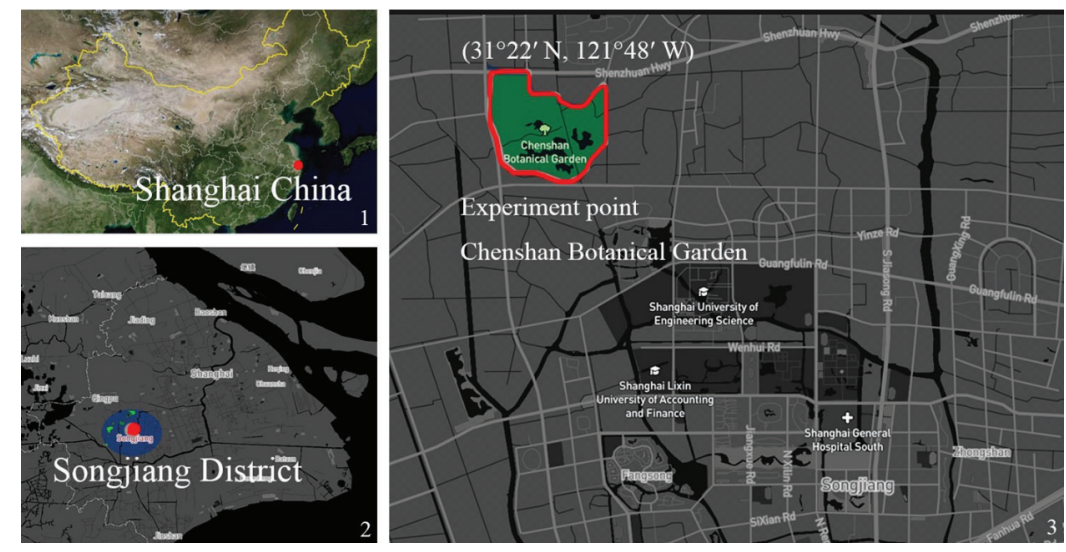

Figure 1: Experimental site 


\subsection{Seedling Culture}

The seedlings of $H$. macrophylla 'Hanatemari' propagated by tissue culture were taken from Hua Jing horticulture company in Hangzhou, Zhejiang Province. In April 2019, the seedlings (height: $3.50 \pm 0.9 \mathrm{~cm}$ and canopy diameter: $13 \pm 0.9 \mathrm{~cm}$ ) were transplanted into plastic pots of $11 \mathrm{~cm} \times 16 \mathrm{~cm} \times 12.5 \mathrm{~cm}$ (bottom diameter $\times$ upper diameter $\times$ height) filled with substrate composed of $10 \%$ perlite, $30 \%$ peat and $60 \%$ compost in volume. The chemical properties were as follows: $\mathrm{pH} 6.5, \mathrm{EC} 0.4 \mathrm{mS} / \mathrm{cm}$, available nitrogen $230 \mathrm{mg} / \mathrm{kg}$, available phosphorus $55 \mathrm{mg} \mathrm{kg}$, available potassium $570 \mathrm{mg} / \mathrm{kg}$. None basal fertilizer was applied to the substrate at the beginning of the experiment.

\subsection{Experimental Design and N Fertilization Regimes}

The $\mathrm{N}$ fertilizer was delivered following the exponential fertilization model [10]:

$r=\operatorname{Ln}\left(N_{T} / N s+1\right) / t$

$N_{\mathrm{t}}=N_{s}\left(e^{r t}-1\right)-N_{\mathrm{t}-1}$

where $\mathrm{r}$ is the relative addition rate required to increase $\mathrm{N}$ from $\mathrm{Ns}$ to $\mathrm{N}_{\mathrm{T}}$, which is calculated with formula (1). $\mathrm{N}_{\mathrm{T}}$ is the total $\mathrm{N}$ application according to the experiment design. $\mathrm{N}_{\mathrm{S}}$ is the initial $\mathrm{N}$ content of the seedlings before fertilizer application. $\mathrm{t}$ is the fertilizer application time. $\mathrm{Nt}$ is the total amount of $\mathrm{N}$ applicated at the $\mathrm{t}^{\text {th }}$ time, and $\mathrm{N}_{\mathrm{t}-1}$ is the total $\mathrm{N}$ application at the $(\mathrm{t}-1)^{\text {th }}$ time fertilization. $\mathrm{N}$ application at $t^{\text {th }}$ time is calculated according to formula (2).

Before fertilizer application, the average initial $\mathrm{N}$ content of Hydrangea seedlings was $0.3 \mathrm{mg}$ per seedling. The total seasonal amount of $\mathrm{N}$ applied was $0.5,1.5$, and $2.0 \mathrm{~g} /$ seedling, denoted as EF1 (exponential fertilization), EF2, and EF3, respectively, and was divided into 12 applications. The plants without fertilizer were the control treatments (CK). In the experiments, urea was used as $\mathrm{N}$ fertilizer, and $\mathrm{N}$ amount was converted to urea dosage according to the $\mathrm{N}$ content in urea.

On 29 May 2019, the first fertilization was applicated. Since then, $N$ fertilizer has been applied every 10 days for a total of 12 times (Tab. 1). The leakage water was collected and reused by placing the pots on a plastic tray. There were 27 seedlings per fertilizer level. The pot experiments were performed with a completely random manner.

Table 1: Nitrogen fertilizer application under exponential fertilization regime

\begin{tabular}{llll}
\hline \multirow{2}{*}{ Fertilization times } & \multicolumn{3}{c}{ Nitrogen dosage (mg/plant) } \\
\cline { 2 - 4 } & EF1 & EF2 & EF3 \\
\hline 1 & 4.41 & 5.96 & 6.39 \\
2 & 6.02 & 8.91 & 9.79 \\
3 & 8.24 & 13.34 & 15.00 \\
4 & 11.26 & 19.96 & 22.99 \\
5 & 15.40 & 29.86 & 35.23 \\
6 & 21.05 & 44.68 & 53.98 \\
7 & 28.78 & 66.86 & 82.73 \\
8 & 39.36 & 100.04 & 126.77 \\
9 & 53.81 & 149.70 & 194.26 \\
10 & 73.57 & 224.00 & 297.68 \\
\hline
\end{tabular}




\begin{tabular}{|c|c|c|c|}
\hline \multirow[t]{2}{*}{ Fertilization times } & \multicolumn{3}{|c|}{ Nitrogen dosage (mg/plant) } \\
\hline & EF1 & EF2 & EF3 \\
\hline 11 & 100.58 & 335.17 & 456.16 \\
\hline 12 & 137.52 & 501.54 & 699.02 \\
\hline Total & 500.00 & 1500.00 & 2000.00 \\
\hline
\end{tabular}

\subsection{Plant Sampling and Chemical Analysis}

\subsubsection{Growth Measurements}

Ten days after the last fertilization, plant height and canopy diameters in two perpendicular directions, one is the widest diameter, of each plant were measured every 10 days. To evaluate plant growth, the plant growth index (PGI) was calculated as the average of the plant height and two canopy diameters $[12,13]$.

\subsubsection{Biomass Determination}

At the end of the experiments, 9 seedlings of each treatment were harvested and washed with doubledistilled water to remove substrate, dust and urea residue from their surfaces. Roots, stems and leaves were collected respectively. These samples were oven-dried at $105^{\circ} \mathrm{C}$ for $30 \mathrm{~min}$, then at $70^{\circ} \mathrm{C}$ to constant weight, dry weight was recorded for each organ.

Total biomass $(\mathrm{g} /$ seedlings $)=$ leaf biomass + stem biomass + root biomass

\subsubsection{Determination of Plant Nutrients}

The samples were grounded with a Wiley mill $(40 \mathrm{mesh})$ for chemical analysis. The samples were digested with microwave digestion method.

To determine the $\mathrm{N}$ content, $0.1 \mathrm{~g}$ sample was digested with $10 \mathrm{ml}$ of sulfuric acid, $3 \mathrm{~g}$ potassium sulphate and $0.2 \mathrm{~g}$ copper sulphate at $230^{\circ} \mathrm{C}$ for $15 \mathrm{~min}$, subsequently, $350^{\circ} \mathrm{C}$ for $15 \mathrm{~min}$ and $420^{\circ} \mathrm{C}$ for $60 \mathrm{~min}$. Nitrogen was quantified by Kjeldahl method (ATN-100 Automatic Azotometer, Shanghai Hongji Instrument Co., Ltd., China).

\subsubsection{Measurement of Chlorophyll Content}

Chlorophyll content was measured by ethanol method; the absorbance was measured with a microplate analyzer (Tecan M200 pro, Austria). The absorbance values at 665 and $649 \mathrm{~nm}$ were measured and calculation formula of chlorophyll $a$, chlorophyll $b$ and total chlorophyll content is as follows: $C_{a}$ is the concentration of chlorophyll a $(\mathrm{mg} / \mathrm{L}), \mathrm{C}_{\mathrm{b}}$ is the concentration of chlorophyll $\mathrm{b}(\mathrm{mg} / \mathrm{L}), \mathrm{C}_{\mathrm{T}}$ is the concentration of total chlorophyll $(\mathrm{mg} / \mathrm{L}), \mathrm{n}$ is the dilution factor, $\mathrm{W}$ is the fresh weight of weighing leaves $(\mathrm{g})$.

$\mathrm{C}_{\mathrm{a}}=13.95 \mathrm{~A} 665-6.88 \mathrm{~A} 649$

$\mathrm{C}_{\mathrm{b}}=24.96 \mathrm{~A} 649-7.32 \mathrm{~A} 665$

$\mathrm{C}_{\mathrm{T}}=\mathrm{C}_{\mathrm{a}}+\mathrm{C}_{\mathrm{b}}=18.08 \mathrm{~A} 649+6.62 \mathrm{~A} 663$

Chl content $(\mathrm{mg} / \mathrm{g})=(\mathrm{C} \times \mathrm{V} \times \mathrm{n}) /(\mathrm{W} \times 1000)$ 


\subsubsection{Root Scan and Soluble Protein Concentration Test}

Image analysis system (winRHIZO) was used to get the data of root morphological index data. The soluble protein contents were determined by the soluble protein content determination kit (Coomassie bright blue method).

\subsection{Data Processing}

The data were presented as average \pm standard error (SE). Statistical difference was tested using analysis of variance (ANOVA) for the completely randomized design and multiple comparison test by SPSS version 24.0 (IBM, Armonk, NY, USA). If ANOVA analysis indicated a significant difference, the Duncan's multiple comparison test was used to separate means. An alpha level of 0.05 for significance was used in statistical analysis. The statistical graphs were produced by Excel 2010 software (Microsoft WA, USA).

\section{Result}

\subsection{Seedling Height, Canopy Diameter and Plant Growth Index}

$\mathrm{N}$ fertilizer promoted growth of 'Hanatemari' Seedlings. Compared with the CK, the height of seedlings in EF1, EF2 and EF3 treatment increased $16.1 \%, 27.5 \%$ and $16.0 \%$, respectively. While the seedling height in EF2 treatment was significantly different from that of CK $(p<0.05)$. As the canopy diameter, another important indicator of the plant growth, both EF1 and EF2 treatments significantly improved the canopy as compared with the control group. However for the EF3 treatment $(2.0 \mathrm{~g} / \mathrm{seeding})$, the canopy diameters were significantly decreased by $23.6 \%$ as compared with the $\mathrm{CK}$, and decreased by $35 \%$ compared with EF1 and EF2 (Fig. 2).

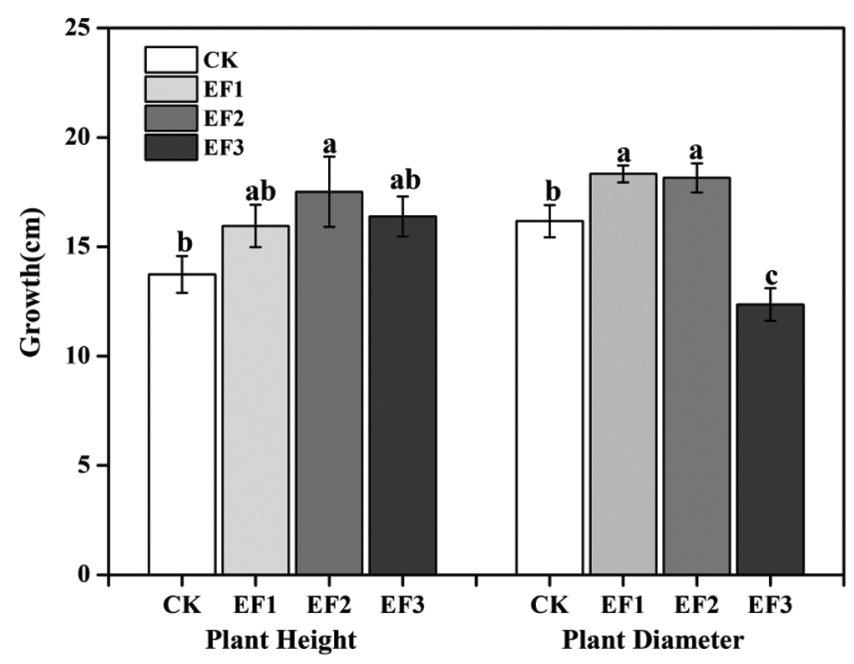

Figure 2: Plant height and canopy diameter of $H$. macrophylla 'Hanatemari' seedlings at different fertilization levels

Notes: Different letters indicate significant differences between treatments $(p<0.05)$.

CK: Control (0 g N/seedling); EF1: (0.5 g N/seedling); EF2: (1.5 g N/seedling); EF3: (2.0 g N/seedling).

The influence of different fertilization levels on the PGI varies (Fig. 3). The PGIs of EF1 and EF2 treatments were significantly higher than that of CK, while there was no significant among these two treatments. Among these three treatments, the optimal PGI appeared in EF2 treatment, which was 16.8\% higher than that of the control. However, the PGI in treatment EF3 was significantly lower than other treatments. Compared with the CK group, it decreased by $10.8 \%$. Therefore, EF2 was the most favorable treatment for PGI, in other words this treatment was the most beneficial for the plant quality improvement, while EF3 was not conducive to the quality of Hydrangea. 


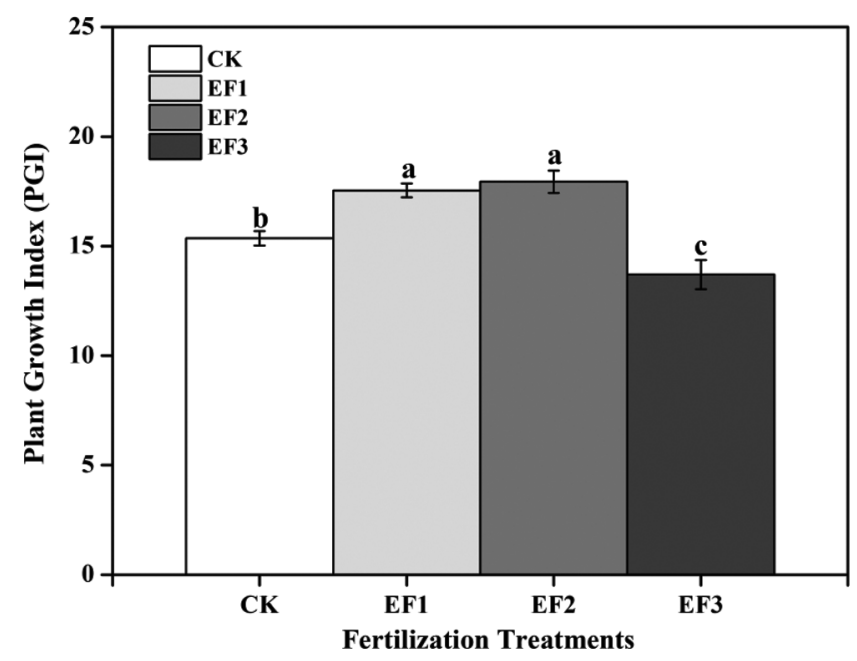

Figure 3: Plant growth index (PGI) under different fertilization levels Notes: Different letters in the same row indicate significant difference at 0.05 level. CK: (0 g N/seedling); EF1: (0.5 g N/seedling); EF2: (1.5 g N/seedling); EF3: (2.0 g N/seedling).

\subsection{Biomass of Seedlings}

The average biomass of $H$. macrophylla leaves ranged from 2.18 to $8.38 \mathrm{~g} / \mathrm{seedling}$ (Fig. 4). The seedlings of EF2 treatment exhibited the highest biomass which was $87.2 \%$ higher than that of the CK. In contrast, in treatment EF3, it was significantly lower than the other three treatments, and its leaves biomass decreased $30.1 \%$ as compared with the CK. The differences of root biomass among EF1, EF2 and CK were not significant, while the EF3 treatment was significantly lower than the control.

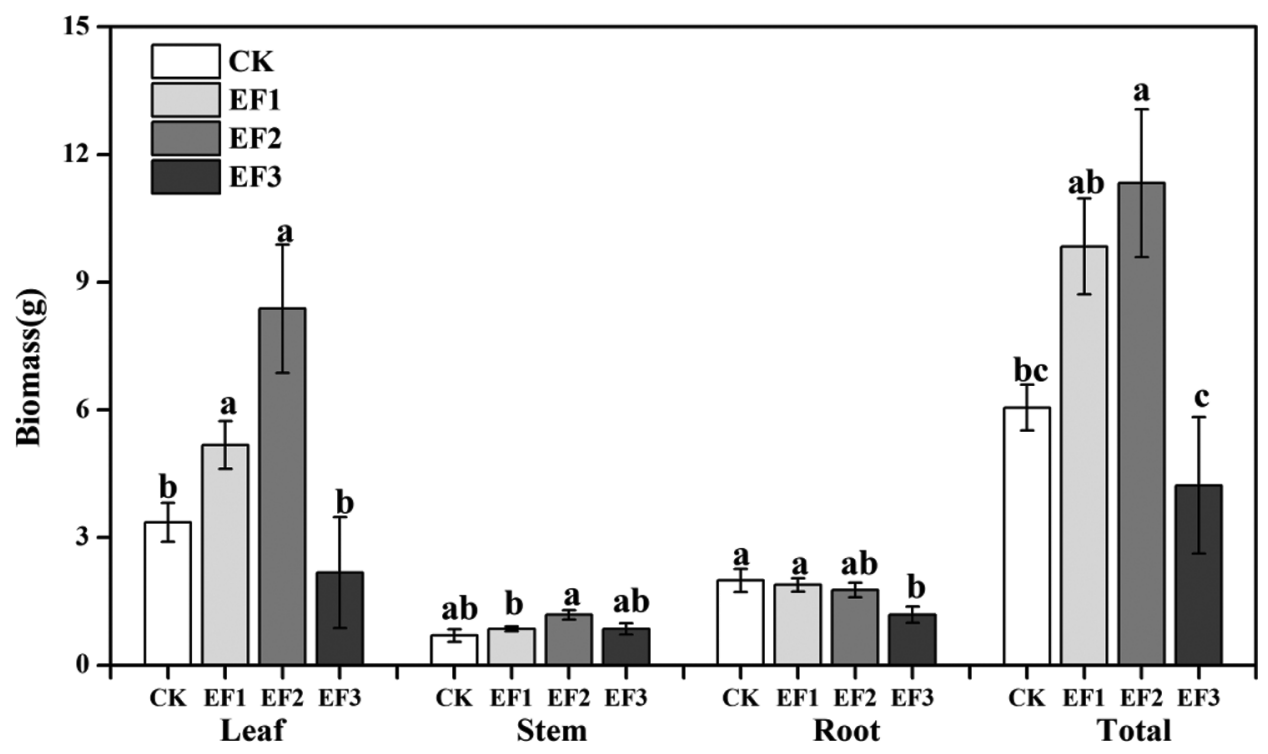

Figure 4: Organ biomass of $H$. macrophylla 'Hanatemari' seedlings at different fertilization levels Notes: Different letters indicate significant differences between treatments $(p<0.05)$. CK: (0 g N/seedling); EF1: (0.5 g N/seedling); EF2: (1.5 g N/seedling); EF3: (2.0 g N/seedling). 
Among all the treatments the highest biomass of leaf, stem, and whole plant was found in EF2 treatment, while the lowest biomass of all the different organs was observed in EF3. In treatments CK, EF1 and EF2, increasing $\mathrm{N}$ fertilization rate increased the biomass of leaf, stem and total plant, whereas the root biomass decreased slightly with the increase of nitrogen application rate.

Furthermore, the ratios of above ground biomass and below ground biomass of EF1 and EF2 fertilization levels were significantly higher than that of control. Whereas, among all these treatments EF2 attained the better ratio, while in EF3 it was lowest (Fig. 5). This parameter varies from 2.18 to 5.38, the highest ratio was $143.8 \%$ higher than that of CK and in EF3 treatment it was just slightly lower than CK treatment with no significant difference. The trend of changes in this indicator indicated that the above ground biomass increases quicker than root biomass within a suitable fertilizer amounts. Excessive fertilization may damage the roots and may have negative effects on the accumulation of aboveground biomass.

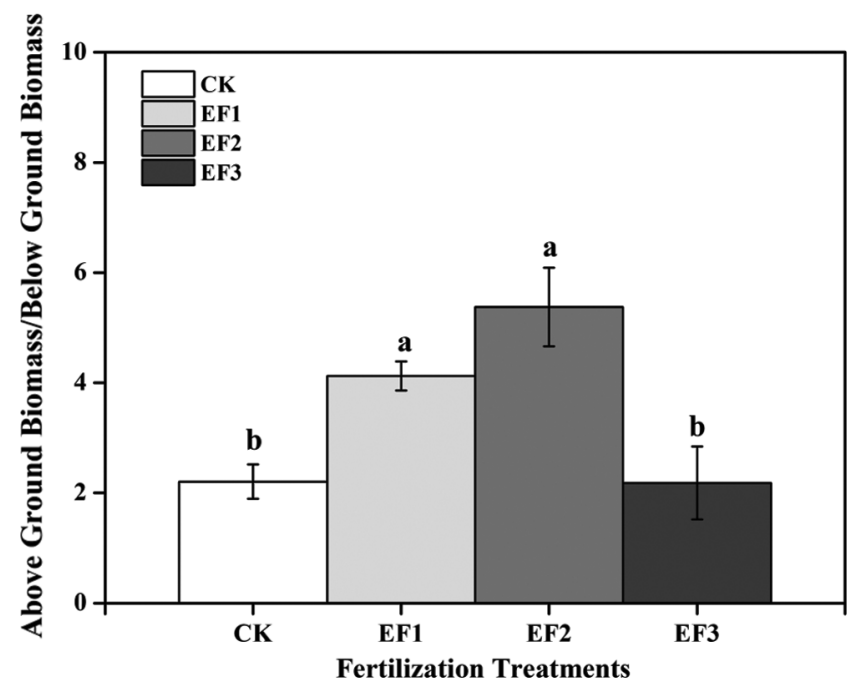

Figure 5: Organ biomass of $H$. macrophylla 'Hanatemari' seedlings at different fertilization levels Notes: Different letters indicate significant differences between treatments $(p<0.05)$. CK: (0 g N/seedling); EF1: (0.5 g N/seedling); EF2: (1.5 g N/seedling); EF3: (2.0 g N/seedling).

\subsection{Root Parameters of H. macrophylla 'Hanatemari'}

From Fig. 6 we can easily see the changes in the morphological indexes of root. The four morphological indexes showed a downward trend as a whole. Root surface area, volume and length slightly increase from CK to EF1 and then had a sharp drop when the nitrogen application rates exceeds EF1 level. When the application level attained to EF3 the average surface area and the length of root was declined about $70.7 \%, 72.5 \%$ and $68.5 \%$ separately as compared with CK. Different from other three parameters root average diameter kept a decline trend from CK to EF3, it started dropping significantly when the application rate exceeds EF2. Our results suggested that compared with CK, the average diameter of roots significantly declined about $68.5 \%$. According to the analysis of four morphological parameters of roots, we speculated that EF1 treatment was the optimal treatment for root growth. 

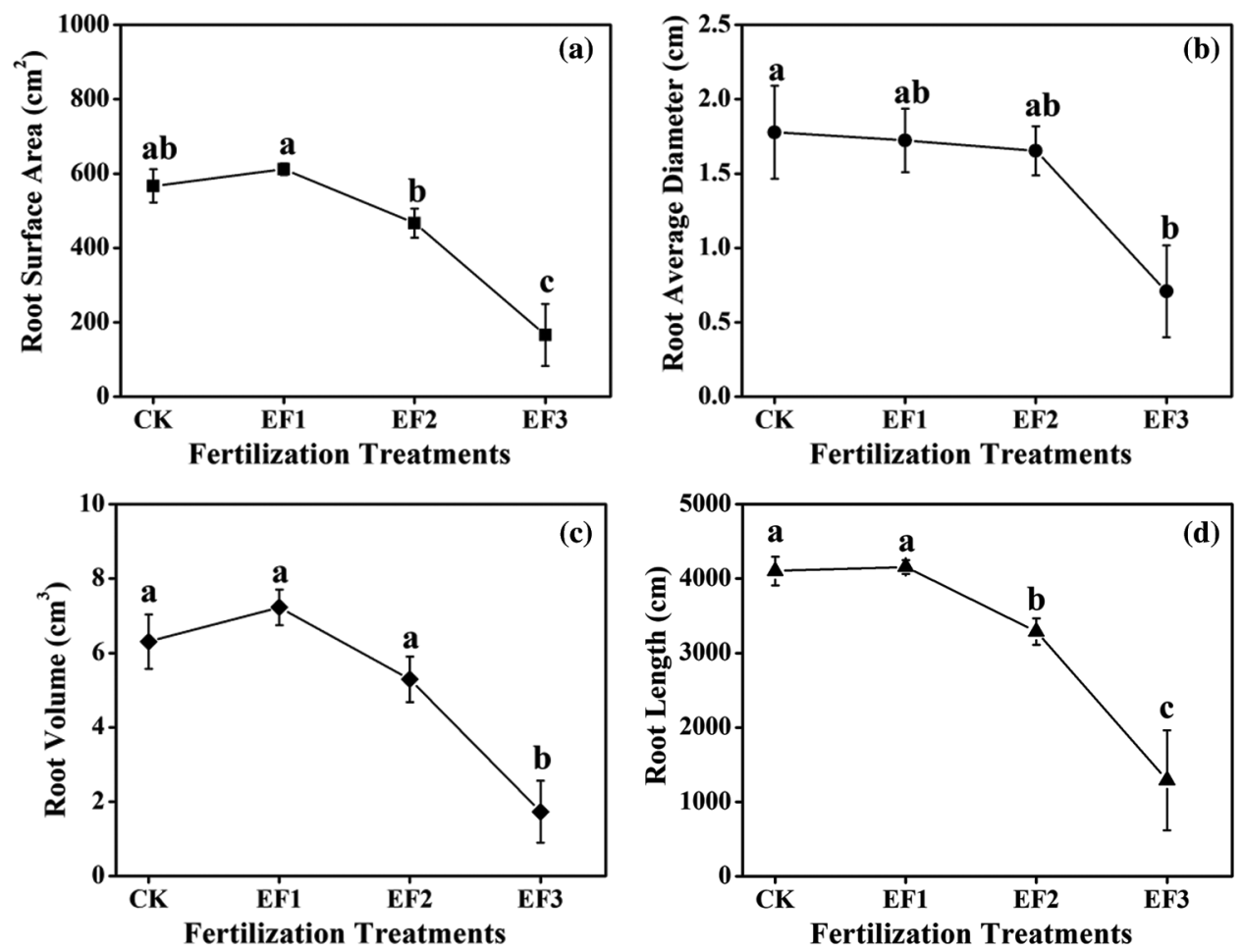

Figure 6: Root parameters of Hydrangea macrophylla'Hanatemari' seedlings at different fertilization levels Notes: Different letters indicate significant differences between treatments $(p<0.05)$. (a) Root Surface Area, (b) Root Average Diameter, (c) Root Volume, (d) Root Length.

CK: (0 g N/seedling); EF1: (0.5 g N/seedling); EF2: (1.5 g N/seedling); EF3: (2.0 g N/seedling).

\subsection{Nutrient Concentration of $\mathrm{H}$. macrophylla 'Hanatemari'}

Overall, fertilization promoted the increase of nutrient concentration in plant. The $\mathrm{N}$ concentrations of H. macrophylla seedlings were in the order of leaf $>$ stem $>$ root (Fig. 7). For the above ground organs, the $\mathrm{N}$ concentrations of fertilization treatments were increased with the increasing of fertilization level. The $\mathrm{N}$ concentration EF3 efficiently increased the nutrient concentration (95.8\%) than the control group. The EF2 treatment's roots nutrition concentration was the highest among all four treatments. Although the N concentration in EF3 was lower than EF2, it did not reach a significant level.

\subsection{Chlorophyll Concentration of H. macrophylla 'Hanatemari'}

The chlorophyll a, b and the total chlorophyll contents were increasing first and then decreasing with the increasing of fertilizer application rates. There were significant differences among different treatments, all the three parameters reached the maximum value in EF1 treatment. Except in EF3, the chlorophyll contents in other two treatments were significantly higher than CK treatment, while the total contents of chlorophyll in leaves of EF3 was $51.5 \%$ lower than control treatment. This indicates that EF3 seriously exceeding the nutrient requirements of 'Hanatemari' (Fig. 8). 


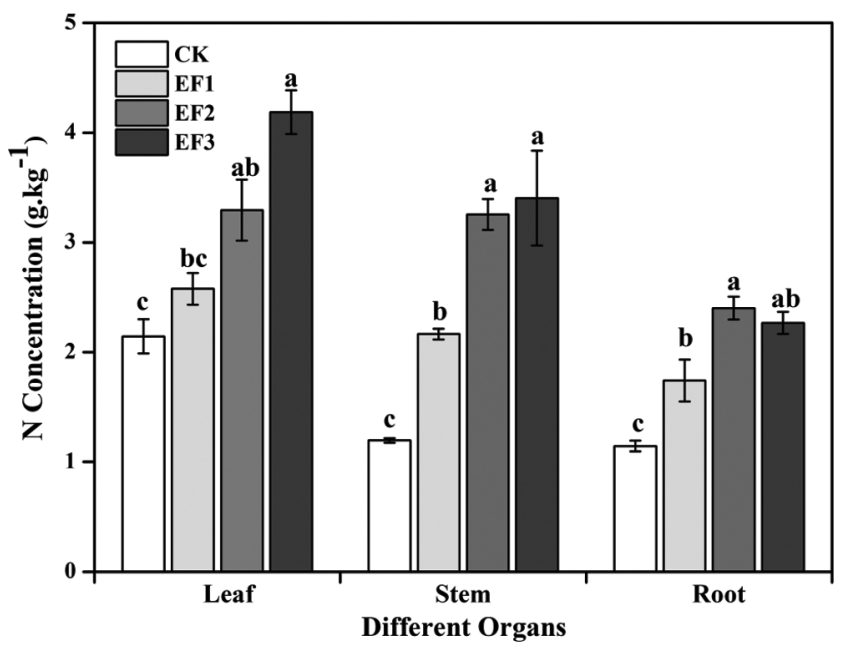

Figure 7: Nitrogen concentration of Hydrangea macrophylla 'Hanatemari' seedlings at different fertilization levels

Notes: Different letters indicate significant differences between treatments $(p<0.05)$.

CK: (0 g N/seedling); EF1: (0.5 g N/seedling); EF2: (1.5 g N/seedling); EF3: (2.0 g N/seedling).

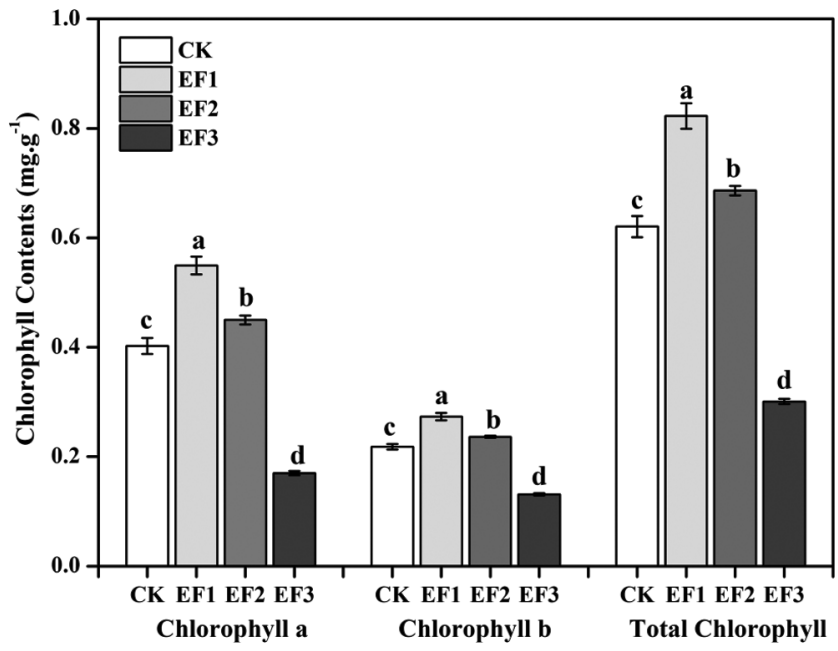

Figure 8: Chlorophyll concentration of Hydrangea macrophylla 'Hanatemari' seedlings at different fertilization levels

Notes: Different letters indicate significant differences between treatments $(p<0.05)$.

CK: (0 g N/seedling); EF1: (0.5 g N/seedling); EF2: (1.5 g N/seedling); EF3: (2.0 g N/seedling).

\subsection{Soluble Protein Concentration of H. macrophylla 'Hanatemari'}

As evidence from Fig. 9, it was concluded that fertilization had no significant effect on the concentration of soluble protein in plant leaves, this parameter varied from 604 to $909 \mu \mathrm{g} / \mathrm{ml}$. The lowest concentration was found in EF1, and by increasing the concentration of fertilizer the concentration of soluble protein just increased slightly. 


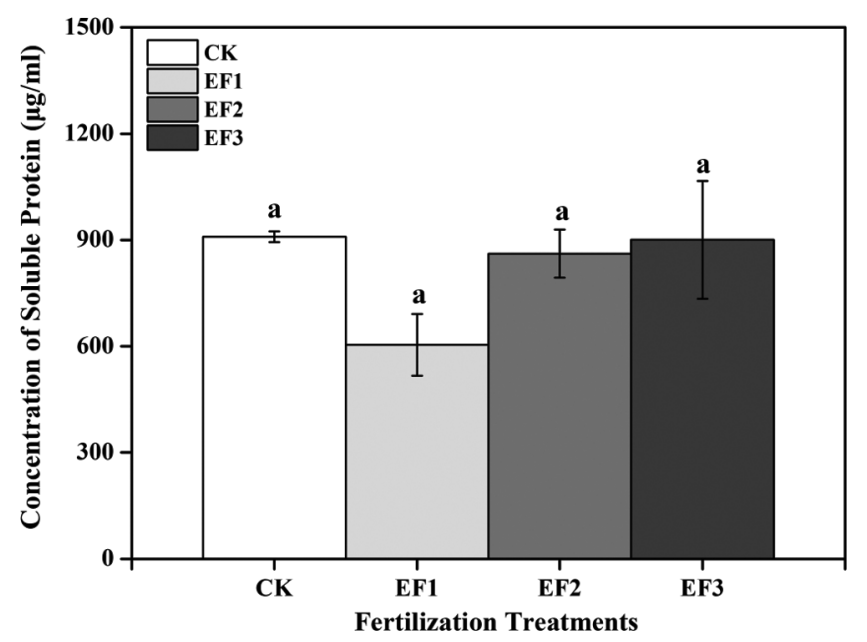

Figure 9: Soluble protein concentration of Hydrangea macrophylla 'Hanatemari' seedlings at different fertilization levels

Notes: Different letters indicate significant differences between treatments $(p<0.05)$.

CK: (0 g N/seedling); EF1: (0.5 g N/seedling); EF2: (1.5 g N/seedling); EF3: (2.0 g N/seedling).

\section{Discussion}

Vegetative growth (plant height, canopy diameter) increased linearly with corresponding increase in nitrogen doses in a suitable range. This may be attributed to the fact that nitrogen is an essential part of chlorophyll and nucleic acids, which might have played major role in promoting plant growth. Furthermore, it encourages the above ground growth of plant. The canopy diameter increased with the increasing of nitrogen rate which may cause by increasing number of shoots and leaves.

The results in general were in agreement with the findings of Cabrera who observed significant increase in plant height in chrysanthemum cv. 'Chandrama' with application of $30 \mathrm{~g} \mathrm{~N} / \mathrm{m}^{2}$ in comparison with the lower doses of nitrogen [14]. Similarly, Ahmad recorded the maximum plant height in Zinnia elegans supplied with higher dose of nitrogen at the rate of $100 \mathrm{~kg} / \mathrm{ha}$ [15]. The results also got support from the findings of Garhwal et al. [16] who had reported that higher doses of nitrogen helped in better vegetative growth, such as plant height number of leaves per plant etc.

Plant growth index (PGI) is important indicators for estimating the quality of ornamental plants which are commonly used in landscape architecture application. The PGI is significantly related to plant height and canopy diameter, and these two parameters are important indicators for estimating the quality of seedlings [17]. In this study these two indicators of fertilized seedlings at EF1 and EF2 treatments were significantly higher than those under the CK treatment. The EF2 treatment had the best PGI, indicating that proper $\mathrm{N}$ application could promote the growth of $H$. macrophylla. 'Hanatemari' seedlings, while excessive application of $\mathrm{N}$ could be toxic to the plant growth. From our research we can easily conclude that PGI increased with increasing $\mathrm{N}$ rate from 0 to $1.5 \mathrm{~g} \mathrm{~N} /$ plant which is similar to the research result of Li et al. [18], in which 'Merritt's Supreme' hydrangea was used as material [18].

Biomass is an important indicator to measure the productivity of seedlings. The total plant biomass increased with the increasing rate of nitrogen among $0,1.0,1.5 \mathrm{~g} \mathrm{~N}$ per plant, the relationship between biomass and fertilization rate also got support from the findings of Bi et al. [19] who worked in Florists' hydrangea in their experiment in 2005 that increasing $\mathrm{N}$ fertilization rate significantly increased plant biomass by $26 \%$. The root biomass decreased slightly as the $\mathrm{N}$ application rate was increased in the exponential fertilization. This is because when $\mathrm{N}$ is deficient, plants increase the proportion of root 
biomass to increase the $\mathrm{N}$ uptake capacity of the roots. The biomass of stems, leaves, and whole plants treated with exponential fertilization showed a trend of increasing first and then decreasing with the increase of total $\mathrm{N}$ application rate, indicating that proper fertilization promoted the growth of rooted cuttings [20], significantly increased the accumulation of dry matter in seedlings [21,22], while excessive $\mathrm{N}$ application caused slight poison to seedlings [23-28], further impeded the seedling growth and biomass accumulation [29,30]. It was found that from EF1 to EF2, even though the biomass was increasing, but not significantly. This finding showed that from 1.0-1.5 g N/plant nutrient supply reached adequate levels. When the nutrition supply rate reached to EF3, the biomass of total plant decreased significantly compared with all other treatments. This result indicated that the EF3 fertilization treatment seriously exceeded the optimal fertilization level of hydrangea. These biomass variation regulation was summarized in Timmer's research in 1996 [1]. In the researches of Li et al. [18] and Bi et al. [19] they found that $25-65 \mathrm{mg} /$ plant was a suitable fertilizer using rage for Pinus resinosa, when the fertilization amount was greater than $65 \mathrm{mg} / \mathrm{plant}$, it caused nutrient toxicity, which indicated that $65 \mathrm{mg} / \mathrm{plant}$ was the optimum nitrogen given level $[18,19]$. The root biomass decreased slightly with the increase of $\mathrm{N}$ application rate. Our results were similar to the reports of Wang et al. [31] which showed the same root biomass variation trend of Chinese fir [8,31]. This may be because the plants need to increase the proportion of root biomass to increase the $\mathrm{N}$ uptake ability of root under the situation of $\mathrm{N}$ deficiency.

$\mathrm{N}, \mathrm{P}, \mathrm{K}$ concentrations among different organs showed different relationships with variations of fertilization rates. Increasing nitrogen fertilization rate could almost increase the $\mathrm{N}$ concentration of leaf and stem, the similar results of nutrition concentration of some other plants and other cultivations of hydrangea had been reported [32,33].

In conclusion, $1.5 \mathrm{~g} \mathrm{~N} /$ plant was the most suitable amount for potted 'Hanatemari' seedling growth. Too low or too high fertilizer application could not promote plant growth effectively. In our study, $2.0 \mathrm{~g} \mathrm{~N} / \mathrm{plant}$ was already exceeding the seedling's $\mathrm{N}$ requirement which resulted in nutrient toxicity, so it was not suitable for cultivation of $H$. macrophylla. Perhaps in future research, we will set more detailed fertilizer gradients to find more accurate fertilization amount for the plant.

Funding Statement: This research is supported by Science and Technology Research Project of Shanghai Greening and City Appearance Administration in 2019 (G192402).

Conflicts of Interest: The authors declare that they have no conflicts of interest to report regarding the present study.

\section{References}

1. Timmer, V. R. (1996). Exponential nutrient loading: A new fertilization technique to improve seedling performance on competitive sites. New Forests, 13, 279-299. DOI 10.1023/A:1006502830067.

2. Pokharel, P., Kwak, J. H., Chang, S. X. (2017). Growth and nitrogen uptake of jack pine seedlings in response to exponential fertilization and weed control in reclaimed soil. Biology and Fertility of Soils, 53(6), 701-713. DOI 10.1007/s00374-017-1213-1.

3. Hawkins, B. J., Burgess, D., Mitchell, A. K. (2005). Growth and nutrient dynamics of western hemlock with conventional or exponential greenhouse fertilization and planting in different fertility conditions. Canada Journal of Forestry Research, 35(4), 1002-1016. DOI 10.1139/x05-026.

4. Finch-Savage, W. E., Bassel, G. W. (2015). Seed vigour and crop establishment: Extending performance beyond adaptation. Journal of Experimental Botany, 67(3), 567-591. DOI 10.1093/jxb/erv490.

5. Razaq, M., Zhang, P., Shen, H. L. (2017). Influence of nitrogen and phosphorous on the growth and root morphology of acer mono. PLoS One, 12(2), 1-13. DOI 10.1371/journal.pone.0171321.

6. Wang, J., Li, G., Pinto, J. R., Liu, J., Shi, W. et al. (2015). Both nursery and field performance determine suitable nitrogen supply of nursery-grown, exponentially fertilized Chinese pine. Silva Fennica, 49(3), 2. DOI $10.14214 /$ sf. 1295 . 
7. Schott, K. M., Pinno, B. D., Landhäusser, S. M. (2013). Premature shoot growth termination allows nutrient loading of seedlings with an indeterminate growth strategy. New Forests, 44(5), 635-647. DOI 10.1007/ s11056-013-9373-9.

8. Leghari, S. J., Wahocho, N. A., Laghari, G. M., Hafeez, L. A., Mustafa, B. G. et al. (2016). Role of nitrogen for plant growth and development: A review. Advances in Environmental Biology, 10(9), 209-219.

9. Veazie, P., Cockson, P., Henry, J., Perkins-Veazie, P., Whipker, B. (2020). Characterization of nutrient disorders and impacts on chlorophyll and anthocyanin concentration of Brassica rapa var. Chinensis. Agriculture, 10(10), 461. DOI 10.3390/agriculture10100461.

10. Dara, S. K. (2019). The new integrated pest management paradigm for the modern age. Journal of Integrated Pest Management, 10(1), 12. DOI 10.3390/agriculture10100461.

11. Liu, X. M., Jin, X., Wu, J. B., Wang, X. L. (2014). The research status and application prospect of nitrogen exponential fertilization on saplings. Soil and Fertilizer Sciences in China, (5), 1-4. DOI 10.11838/ sfsc.20140501 (in Chinese).

12. Clark, M. J., Zheng, Y. (2015). Use of species-specific controlled-release fertilizer rates to manage growth and quality of container nursery crops. HortTechnology, 25, 370-379. DOI 10.21273/HORTTECH.25.3.370.

13. Wang, R., Li, J. Y., Zhang, F. Q., Zhu, B. Z., Pan, W. (2011). Growing dynamic root system of Aquilaria malaccensis and Aquilaria sinensis seedlings in response to different fertilizing methods. Acta Ecologica Sinica, 1, 98-106. DOI 10.1631/jzus.A1010009.

14. Cabrera, R. I., Perdomo, P. (2003). Reassessing the salinity tolerance of greenhouse roses under soilless production conditions. Hortscience, 38(4), 533-536. DOI 10.2307/23264222.

15. Ahmad, I., Ahmad, T., Zafar, M. S., Nadeem, A. (2007). Response of an elite cultivar of zinnia (Zinnia elegans cv. giant dahlia flowered) to varying levels of nitrogenous fertilizer. Sarhad Journal of Agriculture, 23(2), 309.

16. Garhwal, P. C., Yadav, P. K., Sharma, B. D., Singh, R. S., Ramniw, A. S. (2014). Effect of organic manure and nitrogen on growth yield and quality of kinnow mandarin in sandy soils of hot arid region. African Journal of Agricultural Research, 9(34), 2638-2647. DOI 10.5897/AJAR2013.8110.

17. Li, C., Shen, S., Ding, L. (2020). Evaluation of the winter landscape of the plant community of urban park green spaces based on the scenic beauty esitimation method in Yangzhou, China. PLoS One, 15(10), 1-12. DOI 10.1371/ journal.pone.0239849.

18. Li, T. Y., Bi, G. H., Harkess, R., Denny, G. C., Scagel, C. (2019). Nitrogen fertilization and irrigation frequency affect hydrangea growth and nutrient uptake in two container types. Hortscience, 54(1), 167-174. DOI 10.21273/ HORTSCI13513-18.

19. Bi, G. H., Scagel, C. F., Harkess, R. (2008). Rate of nitrogen fertigation during vegetative growth and spray applications of urea in the fall alters growth and flowering of florists' hydrangeas. Hortscience, 43(2), 472-477. DOI 10.21273/HORTSCI.43.2.472.

20. Wang, L. P., Yan, Z. Y., Li, J. Y., Wang, J. H., He, X. et al. (2012). Effects of exponential fertilization on biomass allocation and root morphology of Catalpa bungei clones. Acta Ecologica Sinica, 32(23), 7452-7462 (in Chinese). DOI 10.5846/stxb201203040288 .

21. Malik, V., Timmer, V. R. (1998). Biomass partitioning and nitrogen retranslocation in black spruce seedlings oncompetitive mixed wood sites: A bioassay study. Canadian Journal of Forest Research, 28(2), 206-215. DOI 10.1139/cjfr-28-2-206.

22. Liu, Z. H., Liu, Y., Duan, S. S. (2002). Effects of fertilization methods on seedling growth and drought tolerance of Platycladus orientalisunder different water conditions. Journal of Beijing Forestry University, 24, 56-60 (in Chinese). DOI 10.1007/s11769-002-0026-8.

23. Salifu, K. F., Timmer, V. R. (2003). Nitrogen retranslocation response of young Picea mariana to nitrogen15 supply. Soil Science Society of America Journal, 67, 309-318. DOI 10.2136/sssaj2003.3090.

24. Yu, Z. Y., Dong, J. Q., Fu, W. J., Ye, Z. Q., Li, W. Y. et al. (2019). The transfer characteristics of potentially toxic trace elements in different soil-rice systems and their quantitative models in southeastern China. International Journal of Environmental Research and Public Health, 16(14), 2503. DOI 10.3390/ijerph16142503. 
25. Dai, W., Li, Y., Fu, W., Jiang, P., Zhao, K. et al. (2018). Variability of soil nutrients in forest areas: A case study from subtropical China. Journal of Plant Nutrition and Soil Science, 181(6), 827-835. DOI 10.1002/ jpln.201800134.

26. Fu, W. J., Zhao, K. L., Zhang, C. S., Tunney, H. (2013). Using GIS and geostatistics to optimize soil phosphor and magnesium sampling in temperate grassland. Soil Science, 178(5), 240-247. DOI 10.1097/SS.0b013e31829d463b.

27. Fu, W. J., Jiang, P. K., Zhou, G. M., Zhao, K. L. (2013). Using Moran's I and GIS to study spatial pattern of forest litter carbon density in typical subtropical region. China Biogeosciences Discussions, 10(12), 2401-2409. DOI 10.5194/bgd-10-19245-2013.

28. Yu, S. Y., Chen, Z. L., Zhao, K. L., Ye, Z. Q., Zhang, L. Y. et al. (2019). Spatial patterns of potentially hazardous metals in soils of Lin'an City, Southeastern China. International Journal of Environmental Research and Public Health, 16(2), 246. DOI 10.3390/ijerph16020246.

29. Wen, G. S., Tian, H. T., Zhang, M. R., Jiang, W. W. (2006). Application of chlorophyll fluorescence analysis in forest tree cultivation. Journal of Applied Ecology, 17(10), 1973-1977 (in Chinese).

30. Zhao, K. L., Fu, W. J., Ye, Z. Q., Zhang, C. S. (2015). Contamination and spatial variation of heavy metals in the soil-rice system in Nanxun county, southeastern China. International Journal of Environmental Research and Public Health, 12(2), 1577-1594. DOI 10.3390/ijerph120201577.

31. Wang, Z., Hassan, M. U., Nadeem, F., Wu, L., Zhang, F. et al. (2020). Magnesium fertilization improves crop yield in most production systems: A meta-analysis. Frontiers in Plant Science, 10, 1727. DOI 10.3389/fpls.2019.01727.

32. Islam, M. A., Apostol, K. G., Jacobs, D. F., Dumroese, R. K. (2009). Fall fertilization of Pinus resinosa seedlings: Nutrient uptake, cold hardiness and morphological development. Annals of Forest Science, 66(7), 1-9. DOI $10.1051 /$ forest $/ 2009061$.

33. Wu, J. S., Jiang, P. K., Chang, S. X., Xu, Q. F., Lin, Y. (2010). Dissolved soil organic carbon and nitrogen were affected by conversion of native forests to plantations in subtropical China. Canadian Journal of Soil Science, 90(1), 27-36. DOI 10.4141/CJSS09030.

\section{Supplementary File}

Table S1: Summary of different parameters of H. macrophylla 'Hanatemari'

\begin{tabular}{|c|c|c|c|c|c|c|c|c|c|c|c|c|c|c|}
\hline \multirow{3}{*}{ Treatment } & \multicolumn{4}{|c|}{ Root Parameters } & \multicolumn{9}{|c|}{ Nutrient concentration $(\mathrm{g} / \mathrm{kg})$} & \multirow{3}{*}{$\begin{array}{l}\text { Total } \\
\text { chlorophyll } \\
\text { contents } \\
(\mathrm{mg} / \mathrm{g})\end{array}$} \\
\hline & \multirow{2}{*}{$\begin{array}{l}\text { Surface } \\
\text { area } \\
\left(\mathrm{cm}^{2}\right)\end{array}$} & \multirow{2}{*}{$\begin{array}{l}\text { Average } \\
\text { diameter } \\
(\mathrm{cm})\end{array}$} & \multirow{2}{*}{$\begin{array}{l}\text { Volume } \\
\left(\mathrm{cm}^{3}\right)\end{array}$} & \multirow{2}{*}{$\begin{array}{l}\text { Length } \\
(\mathrm{cm})\end{array}$} & \multicolumn{3}{|c|}{ Nitrogen $(\mathrm{N})$} & \multicolumn{3}{|c|}{ Phosphorous (P) } & \multicolumn{3}{|c|}{ Potassium (K) } & \\
\hline & & & & & Leaf & Stem & Root & Leaf & Stem & Root & Leaf & Stem & Root & \\
\hline $\mathrm{CK}$ & $\begin{array}{l}567.03 \\
\pm \\
44.62 \mathrm{ab}\end{array}$ & $\begin{array}{l}1.78 \pm \\
0.31 \mathrm{a}\end{array}$ & $\begin{array}{l}6.31 \pm \\
0.73 \mathrm{a}\end{array}$ & $\begin{array}{l}4102.91 \\
\pm \\
191.91 \mathrm{a}\end{array}$ & $\begin{array}{l}2.14 \pm \\
0.16 \mathrm{c}\end{array}$ & $\begin{array}{l}1.20 \pm \\
0.02 \mathrm{c}\end{array}$ & $\begin{array}{l}1.14 \pm \\
0.05 \mathrm{c}\end{array}$ & $\begin{array}{l}4.50 \pm \\
0.29 \mathrm{a}\end{array}$ & $\begin{array}{l}2.39 \\
\pm \\
0.19 \mathrm{a}\end{array}$ & $\begin{array}{l}3.13 \pm \\
0.40 \mathrm{a}\end{array}$ & $\begin{array}{l}25.36 \\
\pm \\
1.61 \mathrm{a}\end{array}$ & $\begin{array}{l}18.92 \\
\pm \\
2.03 \mathrm{a}\end{array}$ & $\begin{array}{l}13.57 \\
\pm \\
1.94 \mathrm{ab}\end{array}$ & $0.62 \pm 0.02 \mathrm{c}$ \\
\hline N1 (EF1) & $\begin{array}{l}611.83 \pm \\
15.20 \mathrm{a}\end{array}$ & $\begin{array}{l}1.72 \pm \\
0.21 \mathrm{ab}\end{array}$ & $\begin{array}{l}7.23 \pm \\
0.48 \mathrm{a}\end{array}$ & $\begin{array}{l}4157.47 \\
\pm \\
91.94 \mathrm{a}\end{array}$ & $\begin{array}{l}2.58 \pm \\
0.14 \mathrm{bc}\end{array}$ & $\begin{array}{l}2.16 \pm \\
0.05 \mathrm{~b}\end{array}$ & $\begin{array}{l}1.74 \pm \\
0.19 \mathrm{~b}\end{array}$ & $\begin{array}{l}2.05 \pm \\
0.08 \mathrm{~b}\end{array}$ & $\begin{array}{l}2.61 \\
\pm \\
0.12 \mathrm{a}\end{array}$ & $\begin{array}{l}2.55 \pm \\
0.20 \mathrm{ab}\end{array}$ & $\begin{array}{l}19.1 \pm \\
0.83 \mathrm{~b}\end{array}$ & $\begin{array}{l}16.31 \\
\pm \\
0.72 \mathrm{a}\end{array}$ & $\begin{array}{l}14.46 \\
\pm \\
1.32 \mathrm{a}\end{array}$ & $0.82 \pm 0.02 \mathrm{a}$ \\
\hline $\mathrm{N} 2$ (EF2) & $\begin{array}{l}466.88 \\
\pm \\
39.30 \mathrm{~b}\end{array}$ & $\begin{array}{l}1.65 \pm \\
0.17 \mathrm{ab}\end{array}$ & $\begin{array}{l}5.29 \pm \\
0.61 \mathrm{a}\end{array}$ & $\begin{array}{l}3289.21 \\
\pm \\
175.31 \mathrm{~b}\end{array}$ & $\begin{array}{l}3.29 \pm \\
0.28 \mathrm{ab}\end{array}$ & $\begin{array}{l}3.26 \pm \\
0.14 \mathrm{a}\end{array}$ & $\begin{array}{l}2.40 \pm \\
0.10 \mathrm{a}\end{array}$ & $\begin{array}{l}2.39 \pm \\
0.26 \mathrm{~b}\end{array}$ & $\begin{array}{l}3.24 \\
\pm \\
0.15 \mathrm{a}\end{array}$ & $\begin{array}{l}1.77 \pm \\
0.23 \mathrm{bc}\end{array}$ & $\begin{array}{l}19.77 \\
\pm \\
1.26 \mathrm{~b}\end{array}$ & $\begin{array}{l}15.58 \\
\pm \\
0.24 \mathrm{a}\end{array}$ & $\begin{array}{l}7.88 \pm \\
1.56 \mathrm{bc}\end{array}$ & $0.69 \pm 0.01 \mathrm{~b}$ \\
\hline N3 (EF3) & $\begin{array}{l}166.41 \\
\pm \\
83.52 \mathrm{c}\end{array}$ & $\begin{array}{l}0.71 \pm \\
0.31 \mathrm{~b}\end{array}$ & $\begin{array}{l}1.73 \pm \\
0.83 \mathrm{~b}\end{array}$ & $\begin{array}{l}1292.71 \\
\pm \\
671.61 \mathrm{c}\end{array}$ & $\begin{array}{l}4.19 \pm \\
0.66 \mathrm{a}\end{array}$ & $\begin{array}{l}3.40 \pm \\
0.43 \mathrm{a}\end{array}$ & $\begin{array}{l}2.27 \pm \\
0.10 \mathrm{ab}\end{array}$ & $\begin{array}{l}3.14 \pm \\
0.82 \mathrm{~b}\end{array}$ & $\begin{array}{l}3.48 \\
\pm \\
0.89 \mathrm{a}\end{array}$ & $\begin{array}{l}1.40 \pm \\
0.03 \mathrm{c}\end{array}$ & $\begin{array}{l}22.38 \\
\pm \\
2.93 \mathrm{ab}\end{array}$ & $\begin{array}{l}13.42 \\
\pm \\
0.89 \mathrm{a}\end{array}$ & $\begin{array}{l}5.62 \pm \\
1.86 \mathrm{c}\end{array}$ & $0.30 \pm 0.01 \mathrm{~d}$ \\
\hline
\end{tabular}

Note: Values within a column followed by different lowercase letters indicate the significant difference $(P<0.05)$. 